When the book was published, it created a sensation. This was largely because Dr Wolfson had access to information inside the Soviet Union that no Westerner could obtain. Indeed, the environment which he described was so frightening, that for a long time there was suspicion that the book was really an exercise in disinformation by the CIA. In fact, it was a forthright description written by a man who, because of his work, was able to travel throughout the Soviet Union and gain access to otherwise secret environmental reports.

Now that he has settled down in Jerusalem, Dr Wolfson has decided to embark on a new project. He has begun the publication of a new journal called Environmental Policy Review: The Soviet Union and Eastern Europe. So far there have been two issues, the first in June 1987 and the more recent one in January 1988 . Overall, the journal is a useful compilation and review of environmental problems in the Eastern Bloc. Dr Wolfson's focus is primarily on the Soviet Union, but in the January 1988 edition, in particular, he has commissioned articles about Yugoslavia, Hungary, and Bulgaria.

One of the themes that seems to underlay many of the articles which have appeared in the two issues available so far, is that protest about environmental disruption begins first with the protest but then leads to a form of nationalism. One of the more interesting examples of this occurred in Armenia. The Armenians protested about what was happening to the republic as early as March 1986. Subsequently, that has led to the demonstrations which we witnessed in February 1988. Similarly, there is a nationalist movement in the Russian republic itself which found its first spark because of the concern about the destruction of forests and old churches and homes. That concern with the environment has now blossomed full-blown into nationalism and into an organization called Pamyat which espouses many fascist ideas. Among other things, Dr Wolfson quotes one of the leaders of the movement as complaining that the Latvians and the Georgians do not mind when they despoil Soviet territory. This discussion arose out of the debate over the reversal of Soviet rivers which flowed north. Wolfson, based on his personal recollection, reports that some estimated that the project would cost 50 to 60 thousand million roubles or more. That would have been an enormous burden for the Soviet Union and ultimately was the reason given why the project was put on hold. It also turns out, of course, that those who would have had to bear the burden of the river reversal were those people in the north, whereas it was in the south, in Uzbekistan, that the beneficiaries were located.

What is unique about this journal is that Dr Wolfson can take material published in the general Soviet press, and bring to bear on it his own personal recollections from within the Soviet Union. That provides a perspective which is missing in so much of the work that is done by those of us who write in the West but have never really worked in the Soviet Union.

The one concern that the reader has about this new journal is whether or not Dr Wolfson can continue to provide enough new subjects to make the journal viable. So far, the first two issues do indeed focus on different questions. However, after a time there may be a danger that some of the articles will become repetitive. He has provided us with a list of articles to come, and they do seem to show enough diversity for now. But after a while, unless he brings in other outside Authors in addition to those from Eastern Europe, it may be that we will find there is not enough which is new.

So far, there is promise. For the sake of glasnost, both in the Soviet Union and in the West, let us hope that Dr Wolfson can continue to find subject matter that is fresh and unique. In that way, the Soviets will learn more about themselves and what they are doing to their society.

Marshall I. Goldman, Associate Director Harvard University Russian Research Center Archibald Cary Coolidge Hall 1737 Cambridge Street Cambridge Massachusetts 02138, USA.

\title{
International Sasakawa Environment Prize for 1988 Awarded to World Commission on Environment \& Development and Royal Commission for Jubail \& Yanbu of Saudi Arabia
}

The 1988 International Sasakawa Environment Prize has been awarded to the World Commission on Environment and Development and the Royal Commission for Jubail and Yanbu of Saudi Arabia. As approved by the Governing Council of the United Nations Environment Programme (UNEP) in 1982, this 'is the World Prize in Environment', that is considered to be on distinctional parity with the Nobel Prizes which have no provision for environmental or ecological studies or advances. The winners are chosen by a distinguished international jury.

The selection of the World Commission was based on 'its outstanding report, Our Common Future-a valuable analysis of the environmental problems confronting the world community, and which provides clear and positive guidance for their solution, inter alia through economic growth based on sustainable development'. The report is also credited with raising public awareness and moving forward the concept of sustainable development.

The selection of the Royal Commission of Jubail and Yanbu of Saudi Arabia was based on its successful bringing together of industry and Government and for "excellent planning and implementation of environmentally sound management plans in two cities, Jubail and Yanbu, making them model towns of our time'.

The prizes, of $\$ 25,000$ each, were presented in Bangkok, Thailand-as usual during World Environment Day ceremonies on Sunday, 5 June. On the recommendation of the Selection Committee, UNEP's Executive Director, Dr Mostafa K. Tolba, invited the Chairman, Prime Minster Gro Harlem Brundtland, of Norway, to accept the award on behalf of the World Commission, and the King of Saudi Arabia to designate a senior official to receive the prize on behalf of the Royal Commission.

The Selection Committee, appointed by the United Nations Secretary-General, was chaired by H.E. Pastrano Borrero, former president of Colombia, who, from his nomination in 1970, addressed environmental issues and has continued to be involved in seeking solutions to environmental problems world-wide.

INFORMATION SERVICE United Nations Office at Geneva Palais des Nations CH-1211 Geneva 10 Switzerland. 